Article

\title{
Exploring Residents' Perceptions of Mega Event-Dubai Expo 2020: A Pre-Event Perspective
}

\author{
Mohit Vij ${ }^{1, *(\mathbb{C})}$, Amitabh Upadhya ${ }^{1}$ (), Anu Vij ${ }^{2}$ and Manoj Kumar ${ }^{1}$ (I) \\ 1 School of Business, Skyline University College, Sharjah, 1797, UAE; amitabh@skylineuniversity.ac.ae (A.U.); \\ mkumar@skylineuniversity.ac.ae (M.K.) \\ 2 School of Business Administration, Aldar University College, Dubai, 35529, UAE; anu@aldar.ac.ae \\ * Correspondence: mvij@skylineuniversity.ac.ae; Tel.: +971-505904702
}

Received: 31 December 2018; Accepted: 24 February 2019; Published: 3 March 2019

\begin{abstract}
This study explores the residents' perceptions of economic, socio-cultural and environmental impacts of a mega-event (World Expo 2020) to be held in Dubai, as well as their level of inclination to participate in the event. The event organizers announced a requirement of thirty thousand volunteers to assist them in successfully organizing the mega event. Such events could prove to be landmarks in destination brand building and may lead to an increase in the number of tourists. The purpose of the study is to gauge the level of understanding about the event impacts within the resident population and their willingness to get involved in event organization. Priory studies of perceptions about the economic, cultural and environmental impacts of a mega-event, are well-nigh non-existent, especially for World Expositions. This study explores residents' perception to get a fair idea of how they get involved in a mega event that will surely have profound impacts on the destination. Drawing on stakeholder theory and triple bottom line (TBL) model, the study uses primary data collected from more than two hundred fifty residents of the region, through a structured questionnaire. The data analysis follows a descriptive design supported by SEM and path analysis. Major findings indicate favorable and promising responses from the residents, and brings forth the scope to improve the level of involvement of the residents to make the event a success.
\end{abstract}

Keywords: mega event; World Expo; Dubai; economy; residents' perceptions; tourism impacts

\section{Introduction}

Mega events are perceived as events which are organized on a larger scale with profound impacts on the economy of a country. Bowdin et al. [1] (p 18) defines them as "events that are so large that they affect whole economies and reverberate in the global media". Müller [2] after discussing various typologies of mega events concluded that "mega-events are ambulatory occasions of fixed duration that attract a large number of visitors, have a largely mediated reach, come with large costs and have large impacts on the built environment and the population". Consequently, mega events tend to be extremely resource-intensive, but given their potential to boost cultural tourism and destination brand building, often receive a substantial public subsidy $([3,4])$. Although it is quite evident from previous research that hosting such events creates positive attitudes towards the hosting destination [5], most of these are however post-event studies focused on sports events reoccurring within the same destination [6]. Barring a few attempts, there remains a shortage of scholarly studies conducted exclusively on world expositions (expos) which are organized every five years and at different places. Also, it is believed that such expositions boost industrial activities in the region in general and in the country in particular [7]. It is argued that expos are worthy of further investigation because of lack of scientific studies mainly about their economic, social and environmental impacts [8]. Although few previously conducted studies have analyzed these impacts, only a handful of those took into 
account the residents' perceptions about the event before it has happened. These pre-event perceptions are generally based on speculations which need to be regulated by the organizers to win residents' confidence and eventually their involvement for the successful conduct of the mega event [9].

The current study is an attempt to explore pre-event perceptions of the residents with regards to the event's economic, cultural and environmental impact and the resultant level of involvement of the residents. The study is unique from three perspectives; firstly, it contributes significantly to the body of knowledge about world expositions as mega events, Secondly, the study holds its own, being a pre-event evaluation of residents' perceptions as against abundantly available post event accounts. Finally, the study is conducted in the context of a diverse population mix of more than two hundred nationalities, out of which less than ten percent only are natives to that country. The study is divided into three parts. In the beginning a background of World Expo is presented followed by an analysis of Dubai's infrastructural prowess to organize it in 2020. In the second part, theoretical conceptualization for the study is discussed which is derived from the stakeholders and Triple Bottom Line (TBL) models. This is followed by the methodology adopted to conduct the study. Lastly, based on the statistical analysis, inferences are drawn leading to significant recommendations to the organizers of Dubai Expo 2020.

\subsection{Brief About World Expositions}

Organizing a World Expo is believed to be an opportunity for demonstration of social-cultural, and economic achievements and its projections, by the host country to the world at large, and in the process raise the profile of the host city. Increasingly, these events, have integrated elements of entertainment for mass consumption [10]. The Expos are events organized at a very large scale mostly by the government of the host country eliciting participation from a large number of countries and international organizations from all across the globe [11] remarked that the character of world expositions has evolved since their inception in 1851 . He goes on to identify three eras of the expos so far into, "the era of industrialization, the era of cultural exchange, and the era of nation branding". During the era of industrialization, the world expositions were fixated on trade, and were well known for the show of innovative developments and progressions. During the second era (1939-1987), the focus was shifted to specific cultural themes, forecasting a better future for the community at large. However, from 1988 till present, the focus has been on positioning the host country through showcasing its strengths. The initial focus on showcasing and transacting products, for which the expos were started, gradually gave way to an exhibition of newer technologies and innovative ideas besides providing a suitable platform for international exchanges. The participating countries and international organizations plan, design and build their pavilions in view of their own social and cultural foundations and level of science and innovation, aligned with the theme of the expo. In addition to the pavilions, various other events involving cultural and artistic performances by participating countries, forums for presentations and deliberations on specific topics and celebrations are commonly seen.

Some well-known landmarks (which later became tourist attractions) were created during the World Expositions, for example, the Victoria and Albert Museum was funded by the profits from the Great Exhibition in 1851, Eiffel Tower was built as entrance archway to the event in 1889, Atomium in Brussels in 1978, Seattle Space Needle Building in 1962 and World EXPO Museum, Shanghai in 2010.

\subsection{Dubai and Expo 2020}

Over the past two decades, as a result of the government's planned approach, the United Arab Emirates (UAE), has successfully diversified from an economy predominately reliant upon oil, to the growth of a thriving tourism sector [12]. Dubai continues to stand out as a brand in itself amongst the seven Emirates of the UAE of which Abu Dhabi is the capital. According to the latest data published by the Department of Tourism and Commerce Marketing (Dubai Tourism), Dubai is nearing its 2020 tourism target as it welcomed a total of 15.79 million visitors in 2017, up by 6.2 per cent over a year earlier [13]. 
The challenges of organizing such a mega event are many, however Dubai has proved to be a destination capable for handling a big event with its state-of-the-art infrastructure both in the accommodation and transport sectors. UAE has the distinction of having one of the world's busiest international airports in Dubai while its shipping port at Jebel Ali is consistently ranked among the best container ports in the world. Dubai transport sector has shown enormous growth in the last decade. The Roads and Transport Authority (RTA) which is responsible for the ground transportation, has successfully introduced various modes of inter-city transportation, such as Dubai bus, Dubai tram, Water taxi, Dubai metro, in addition to long existing Dubai taxi. The authority has also undertaken multiple initiatives in integrating modern technology by launching eight mobile apps over the last five years. Currently, the transport sector in Dubai seems to be ready for meeting the challenges of organizing a mega event, such as the World Expo 2020. The nation is host to one of the world's busiest airplane terminals-Dubai Airport, which serves more than sixty million people a year, flying to over two hundred sixty destinations through more than one hundred forty scheduled airlines. Aiming at attracting hundred million passengers by 2020, the airport expansion is under way. Due to its strategic location, Dubai has always been a focal point for sea trade. Jebel Ali, one of its ports, is the biggest marine terminal in the Middle East and tenth largest container port in the world. Providing market access to more than two billion people, the port presents an integrated multi-model hub offering air, land and sea connectivity. The accommodation sector in Dubai and the neighboring emirates is also expanding. In anticipation of the influx of visitors during the world expo, a large amount of room inventory is being added to the country. Out of the 200 new hotel projects currently ongoing across UAE, 164 belongs to the emirate of Dubai.

The emirate of Dubai has also been home to MICE (meeting, incentive, conference, and exhibition) tourism. Established in 1979, the Dubai World Trade Centre hosts major international events, such as Arabian Travel Market which is a landmark in the history of tourism and hospitality exhibitions. Culturally, UAE emerges as a cosmopolitan country hosting more than two hundred nationalities consisting of eighty five percent of its ten million population. According to a report issued by the Institute for Global Development in Switzerland, UAE ranks third globally in the National Culture Index for its mix of openness, generosity and tolerance. The country is also known for a variety of cultural establishments and events. All the leading emirates have marked their presence on the global map through hosting annual events, such as the Emirates Airline Festival of Literature, Abu Dhabi Festival and the Dubai and Abu Dhabi Film Festivals and the Sharjah Biennial. The country promotes the idea of happiness and positive lifestyle through a legislative initiative that is one of its kind-a dedicated Ministry of State for happiness!

Thus, the current observations suggest that the emirate of Dubai in the UAE possesses the savoir-faire and wherewithal to host the World Expo 2020. Twenty-five million visitors are expected to attend the Dubai Expo 2020 and over 70 percent of those attending will be international guests [14]. According to projections by the Oxford Economics, "Dubai Expo 2020 is expected to account for a total economic output of nearly 142 billion UAE Dirhams (1 USD = 3.67 UAE Dirhams as officially pegged) with 277,000 employment opportunities being created between 2013 and 2021."

With this background the current study aims at analyzing the residents' perceptions about the impacts of upcoming Expo 2020; significant factors affecting these perceptions; residents' willingness to be involved; and the relationships among residents' perceptions and willingness to be involved in the event.

\section{Theoretical Framework and Conceptualization}

The theoretical foundation of this study rests on the "stakeholder theory" which was initially proposed by Freeman [15] (p. 46) in regard to organizational stakeholders when he stated that "an organization can be characterized by its relationships with the organization's stakeholders". He defined a stakeholder as "an individual or group that can affect or is affected by the achievement of the organizational goals". The theory was further refined by Donaldson \& Preston [16] who clarified that 
a "stakeholder whether an individual or group must have a legitimate interest in the organization". Stakeholder theory has now been fairly established in the literature of business management since it first appeared in the eighties [17]. Applying the theory in tourism management, Byrd, Cárdenas, \& Greenwood [18] investigated stakeholder involvement and public participation in regard to sustainable tourism development. Stakeholder participation they believe, is affected in different forms both informal and formal and may include advisory committees, stakeholder surveys, focused group interviews, deliberations with public, and review panels of prominent citizens, collaboration, and public hearings [19] as such, for successful stakeholder involvement effective mechanisms are needed to implement participation. Byrd, Cárdenas, \& Greenwood [18] further believe that despite skepticism towards the possibility of stakeholder involvement any tourism development shall be meaningless and may remain just a marketing slogan and this involvement allows for a "stronger understanding of the tourism impacts that the community perceives and the actual impacts that result from tourism". Cerutti [20] in a comparatively recent work have discussed the involvement of stakeholders in the context of small and medium religious events and festivals and conclude that the involvement generates positive socio-cultural impacts. Raj, Walters, \& Rashid [21] in similar contexts believe that the larger the event it may have more aims to achieve since there will then be several sub-events and as a result more stakeholders. Since the present study is in regard to a mega event it will not be out of place to mention that sufficient literature is available that has attempted to classify events and propose typologies from the thematic to the scale of organization of the event [21,22]. World Expo as a special event is considered to be a significant tourism activity due to its impacts in terms of promoting the host city brand, attracting a number of visitors and creating an opportunity for economic benefits for the residents [23,24]. However, it is imperative for the destination authorities to win the confidence of the local residents before taking any decision related to organizing such a mega tourism event like a world expo [25,26]. Rather, the inhabitants of a region, should be included from the very beginning in any kind of planning of such tourism development. Many studies [27-30] stipulated that the residents shall be willing to support the growth of tourism in a region, if they are also consulted in the planning process, and also if they find that their needs are taken into account by the development authorities and other stakeholders. The level of participation of residents/citizens in tourism planning mostly depends on their ability to influence the planning process and their perception that they can actually influence the overall planning decisions. This influence on the planning process is determined by the personal involvement of the inhabitants, in addition to the resources available to them which support involvement [31]. Receiving full support from the local residents has always been a challenging task for the authorities. Barring many possible benefits which are connected with tourism (such as taking economic decisions through the local community, decrease in unemployment, local budget income, improvement of local infrastructure) residents also perceive potential drawbacks of tourist activity for example noise, environment pollution, acts of violence, congestion and so on. Vij [32] while presenting a big picture of Dubai's preparations for the mega event, referred to the Expo 2010 Shanghai China where NGOs protested against displacement of families, employees were forced to visit the Expo to meet the target of 70 million visitors. A lot depends on the residents' perceptions about the particular tourism activity, tourists and perceived impacts. In general, perception consists in the "meaning assigned to an object, resulting from the individual selection, decoding and interpretation of external information; it is a representation of reality" [33]. Drawing on a discussion of perceptions of residents of Shanghai on the 2010 Expo and its impacts on their lives, Yang, Zeng, \& Gu [34] classified community residents into three groups: favorers, realists, and haters, wherein only six percent of the sample was found to be in the last category. However, the results may differ in a different backdrop of economic and cultural setting. Li, Hsu, \& Lawton [35] found that Shanghai residents' perception changes throughout the Expo 2010 full life cycle and the residents' perceived impacts at the community level were more positive than at the individual level. Role of media and marketing campaigns to promote the social and economic implications of the event and also to explore opportunities through which the residents could be involved in the whole process of planning and implementation, has been 
highlighted in the previous studies [36]. In contrast to the findings of many studies establishing a positive relationship between willingness to host the event and residents' perception of economic impacts, Balduck, Maes \& Buelens [37] found that the more residents believed the event generates economic and tourism development, the less willing they were to host the event next year. Residents believed that more economic development implicates more noise and traffic pollution, growth of industrial sites, perhaps in or around district neighborhoods.

The study also conforms to a triple bottom line approach as another theoretical plank; special events have become the fastest growing sectors of the tourism industries and are instrumental in an increase in the attraction appeal of destinations [38] as such the question of evaluation of impact of these events before and after the event, is gaining more traction. Having traditionally been considered only as an image building and economic activity, events are now being viewed from a larger perspective with equally significant environmental and social implications. Since governments have generally been responsible for the conduct and more so allocation of resources, to support a special event that may include infrastructure, superstructure and opportunity costs, it is becoming well-nigh essential to take a 'holistic approach' in assessing the impacts of an event.Dwyer \& Jago [39] believe that for such an inclusive evaluation, the 'triple bottom line' approach is highly suitable. Wise [40] considers that the triple bottom line approach is now widely recognized by scholars, teachers, planners and businesses in the area of tourism while planning for sustainable tourism futures. The triple bottom line concept expands the notion of performance evaluation to include not only the traditional financial bottom line, but also the social and environmental [41]. The present study, taking a clue from the established effectiveness of the concept, pins its design on this approach besides the stakeholder theory, as is evident from the framing of the hypotheses discussed ahead.

The design of this study thus, is firmly grounded in the appropriate theoretical framework. It is quite evident from the literature available in public domain that stakeholders do carry perceptions about events and take an active interest in the resultant impacts leading the current study to analyze and evaluate the triple bottom line of economic, social and environmental perceived implications. Subsequently, several indicators and sub-indicators have been identified in order to measure the stakeholders' participation, which has been discussed in the previous studies, such as the perceived impacts of tourism development [42]; stakeholder knowledge [8]; support for tourism development [43]; community attitudes toward tourism development [44]. The hypothetical framework is an adaptation from [45] in which five latent constructs of tourism development and community satisfaction were considered. The proposed framework however, is a pre-event evaluation thus replacing the satisfaction construct with involvement and participation in the event based on the residents' perception of impacts. Each path in the framework (Figure 1) represents a hypothesized relationship with the direction of effect identified as either positive (+) or negative (-).

In the light of the literature reviewed and the subsequent discussion, the following hypotheses are proposed to be tested with appropriate empirical analysis.

H1a: Positive Economic Perception of Expo 2020 positively impacts involvement of residents towards Expo 2020.

H1b: Negative Economic Perception of Expo 2020 negatively impacts involvement of residents towards Expo 2020.

H2a: Positive Social Perception of Expo 2020 positively impacts involvement of residents towards Expo 2020.

H2b: Negative Social perception of Expo 2020 negatively impacts involvement of residents towards Expo 2020.

H3a: Positive Environmental Perception of Expo 2020 positively impacts involvement of residents towards Expo 2020.

H3b: Negative Environmental Perception of Expo 2020 negatively impacts involvement of residents towards Expo 2020. 


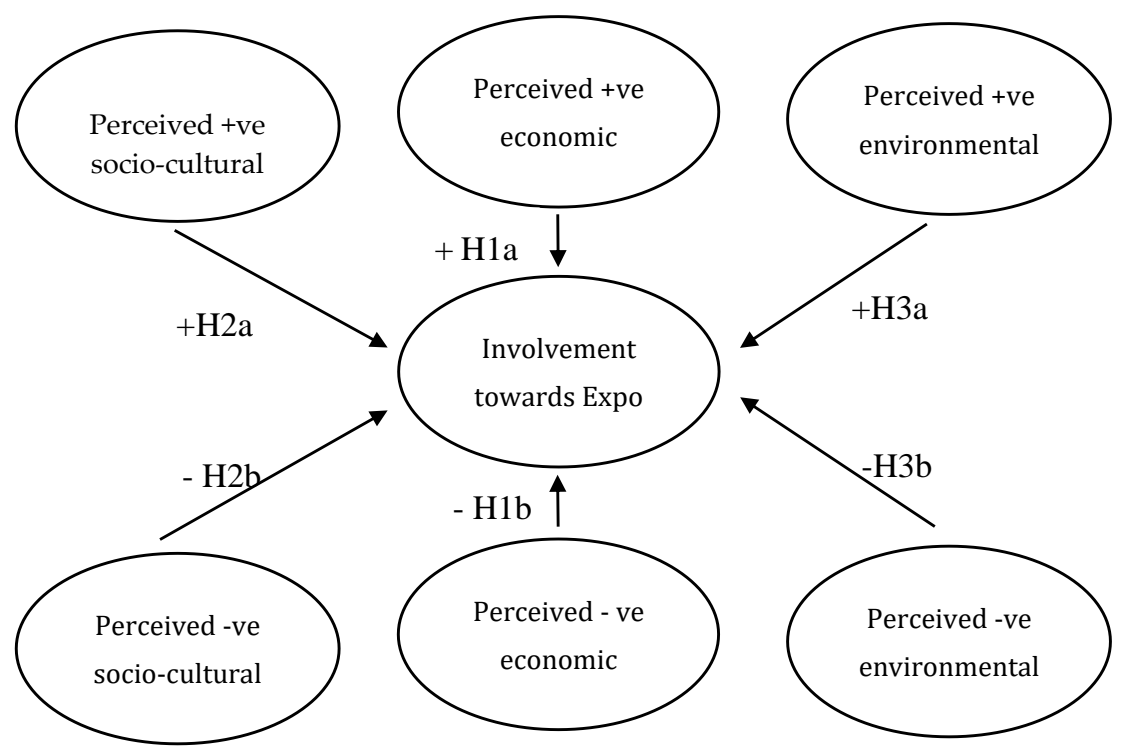

Figure 1. Proposed framework to measure relationships between residents' perceived impacts of the event and their inclination to be involved.

\section{Methodology}

The present study is based on primary data collected through a structured questionnaire administered to the residents of Dubai. The questions asked in the questionnaire were framed on the premise that residents' perceptions towards any kind of tourism development can be categorized under the economic, social and environmental dimensions as previously established in research work [46-52]. Initially as many as thirty-six questions were framed as part of a pilot study conducted on a set of respondents consisting of thirty-eight postgraduate university students who were assigned the survey and evaluated on a project in their course work. Based on the results received, the questionnaire was revised, and the number of questions was reduced to twenty-seven. The questionnaire was divided into four broad sections. The first section included nine items on the economic impacts drawn from the studies of [53-57]. The second section included six items on environment impacts drawn from the studies of $[55,58-60]$. The third section included eight items on sociocultural impacts drawn from the studies of $[23,57,58,61]$. The last section included four items on the respondents' involvement in the event through gauging their awareness and intention to participate as a volunteer or to simply promote a positive word of mouth, drawn from [62-64]. All responses were taken on a 5-point Likert scale where one indicates 'strongly disagree', two indicates 'disagree, three indicates 'neutral', four indicates 'agree', and five indicates 'strongly agree' [65]. The authors used an interviewer-administered method of delivery as it enabled them to clarify respondents' queries related to certain words, as and when required. However, considering that more knowledge about tourism could promote more positive perceptions about tourism activity [47], creating interviewer effects, clarification was offered only when requested. An effort was made to maintain diversity in the sample by collecting responses from students of different Universities and also families visiting malls, during the months of May, June and July 2018. Thus, the survey was conducted on a next-to-pass basis that is, when one respondent finished the questionnaire the next person to pass the survey point, was requested to take part in the survey. This method minimizes the utilization of surveyors and interviewer bias in the choice of individuals for survey as-such the surveyor does not have to choose who to survey [66]. A total of 300 residents over a specified period were surveyed, however 253 filled questionnaires (without any ambiguity) were received yielding a response rate of $84 \%$. The data were analyzed using SPSS 16 and SAS system, using bivariate methods and Structural Equation Modeling. The model was applied to determine dependencies between the latent exogenous variable representing "involvement" and the latent endogenous variables viz; economic impacts, socio-cultural impacts and environmental impacts. 


\section{Findings and Analysis}

The data were tested for reliability to evaluate the stability and consistency for measured items of each construct. Cronbach's Alpha was found to be 0.896 for the entire list of items and more than 0.7 for each category (Table 1). There were no cases excluded from the analysis and all the responses were found to be valid.

Table 1. Item wise Cronbach $\alpha$.

\begin{tabular}{cc}
\hline Latent Variables & Cronbach $\alpha$ \\
\hline Positive Economic & 0.881 \\
\hline Positive environment & 0.791 \\
\hline Positive social & 0.898 \\
\hline Involvement & 0.869 \\
\hline Negative Economic & 0.740 \\
\hline Negative Environment & 0.763 \\
\hline Negative Social & 0.861 \\
\hline
\end{tabular}

Table 2 displays the demographics of the respondents. Although an effort was made to receive responses from a diverse set of respondents, no specific methodology was adopted to reach them category-wise. However, an attempt was made to access them in the educational institutes (young respondents) and shopping malls (respondents with families). Considering the fact that the United Arab Emirates' population consists of 61 percent of people in the age group of 25 to 54 years, more than 65 percent of the sample consisted of this age group. The males in the sample outnumbered females due to the challenge of randomly contacting females, given the conservative culture in the country. In terms of occupation status, 37 percent of the respondents were running their own businesses, followed by 27 percent working for private companies. Interestingly 26 percent of the respondents were drawing a monthly income of more than AED 30,000 (US\$ 8175), followed by 21 percent having nil income (who might be students in the universities or unemployed).

Table 2. Demographic profile of respondents $(\mathrm{N}=253)$.

\begin{tabular}{ccc}
\hline Demographic Variable & Frequency & Percentage \\
\hline \multicolumn{3}{c}{ Age } \\
\hline Below 25 & 52 & 20.6 \\
$26-35$ & 69 & 27.3 \\
$36-45$ & 70 & 27.7 \\
$46-55$ & 37 & 14.6 \\
56 Above & 25 & 9.9 \\
Total & 253 & 100.0 \\
\hline \multicolumn{4}{c}{ Gender } \\
Male & 152 & 60.1 \\
Female & 101 & 39.9 \\
Total & 253 & 100.0 \\
\hline & Marital Status \\
Married & 207 & 81.8 \\
Total & 46 & 18.2 \\
\hline
\end{tabular}


Table 2. Cont.

\begin{tabular}{ccc}
\hline Demographic Variable & Frequency & Percentage \\
\hline & Occupation & \\
\hline Government Job & 47 & 18.6 \\
Private Job & 86 & 34.0 \\
Business & 80 & 31.6 \\
Student & 40 & 15.8 \\
Total & 253 & 100.0 \\
\hline & Income & \\
\hline Nil & 17 & 6.7 \\
Below 5000 AED & 17 & 6.7 \\
5001-10,000 & 13 & 5.1 \\
10,001-15,000 & 27 & 10.7 \\
15,001-20,000 & 19 & 7.5 \\
20,001-25,000 & 29 & 11.5 \\
25,001-30,000 & 52 & 20.6 \\
30,000 and above & 79 & 31.2 \\
Total & 253 & 100.0 \\
\hline
\end{tabular}

For the analysis of data; mean, standard deviation and ranking were calculated (Table 3). Higher mean value and ranking indicates the intensity of responses towards the variable. Out of the 27 statements in questionnaire, "The event will cause price increase of basic items" emerged with highest mean (mean ranking 1) while mean ranking 2 was associated with the variable, followed by variable statement "The event will cause price increase of real estate (land prices, housing prices/rent)" "Dubai Expo 2020 will promote tourism in the country", receiving the third rank. Interestingly, out of the top ten mean ranks, seven ranks were attained by the economic impact variables, three ranks by socio-cultural impacts variables and one rank by the environmental impact variables (rank nine was shared by both-economic and socio-cultural impacts variables).

Table 3. Mean, standard deviation and ranking.

\begin{tabular}{|c|c|c|c|c|c|}
\hline & Measure & Mean & Std. Deviation & Rank & Percentage Agree \\
\hline \multicolumn{6}{|c|}{ Economic impacts } \\
\hline 1 & Dubai Expo 2020 will attract more economic investments in the country & 3.74 & 0.87 & 4 & $60 \%$ \\
\hline 2 & $\begin{array}{l}\text { Our living standards will improve because of the money that will be received from } \\
\text { the visitors during Dubai Expo } 2020\end{array}$ & 3.41 & 0.91 & 11 & $48 \%$ \\
\hline 3 & The event will cause a price increase of basic items & 4.26 & 0.76 & 1 & $83 \%$ \\
\hline 4 & The event will cause a price increase of real estate (land prices, housing prices/rent) & 4.14 & 0.71 & 2 & $84 \%$ \\
\hline 5 & It will lead to employment generation & 3.58 & 0.91 & 7 & $53 \%$ \\
\hline 6 & Dubai Expo 2020 will improve the infrastructure & 3.52 & 0.98 & 9 & $53 \%$ \\
\hline 7 & Dubai Expo will promote tourism in the country & 3.88 & 0.90 & 3 & $70 \%$ \\
\hline 8 & I think that many people might lose their jobs after the event is over & 1.96 & 0.85 & 20 & $04 \%$ \\
\hline 9 & $\begin{array}{l}\text { I feel that Dubai Expo } 2020 \text { will bring more positive impacts to the economy than } \\
\text { negative impacts }\end{array}$ & 3.61 & 1.05 & 6 & $55 \%$ \\
\hline \multicolumn{6}{|c|}{ Environmental impacts } \\
\hline 10 & $\begin{array}{l}\text { The event will result in gaining money to be used on preservation and } \\
\text { conservation of environment }\end{array}$ & 2.77 & 0.93 & 17 & $29 \%$ \\
\hline 11 & Dubai Expo 2020 will lead to pollution (air, water, noise) & 3.15 & 0.97 & 13 & $39 \%$ \\
\hline 12 & $\begin{array}{l}\text { I expect that the city will be more populated due to the migration of people during } \\
\text { the event }\end{array}$ & 3.36 & 0.86 & 12 & $45 \%$ \\
\hline 13 & I expect congestion due to traffic increase even during the preparation of the event & 3.42 & 0.82 & 10 & $47 \%$ \\
\hline 14 & $\begin{array}{l}\text { Construction of hotels and other facilities for the event will destroy the natural } \\
\text { environment }\end{array}$ & 3.01 & 0.91 & 14 & $8 \%$ \\
\hline 15 & $\begin{array}{l}\text { I feel that Dubai Expo } 2020 \text { will bring more positive impacts to the environment } \\
\text { than negative impacts. }\end{array}$ & 2.99 & 0.92 & 15 & $53 \%$ \\
\hline
\end{tabular}


Table 3. Cont.

\begin{tabular}{|c|c|c|c|c|c|}
\hline & Measure & Mean & Std. Deviation & Rank & Percentage Agree \\
\hline \multicolumn{6}{|c|}{ Socio-cultural impacts } \\
\hline 16 & $\begin{array}{l}\text { Having visitors from all over the world during the event makes me feel proud of } \\
\text { my country }\end{array}$ & 3.52 & 0.85 & 9 & $48 \%$ \\
\hline 17 & Dubai Expo will strengthen the Dubai Brand in the international marketplace & 3.67 & 0.88 & 5 & $52 \%$ \\
\hline 18 & Dubai Expo will result in the availability of recreational facilities for the residents & 3.57 & 0.96 & 8 & $50 \%$ \\
\hline 19 & The event will cause changes in the traditions and culture of the community & 2.08 & 1.93 & 19 & $8 \%$ \\
\hline 20 & $\begin{array}{l}\text { Dubai Expo will lead to an increase in anti-social elements (like crime, } \\
\text { prostitution, drugs) }\end{array}$ & 2.45 & 0.96 & 18 & $17 \%$ \\
\hline 21 & $\begin{array}{l}\text { Residents suffer from a lower quality of life as a result of preferences given to } \\
\text { the visitors }\end{array}$ & 2.08 & 0.95 & 19 & $9 \%$ \\
\hline 22 & I am worried about the inconvenience to the general public & 2.82; & 1.04 & 16 & $30 \%$ \\
\hline 23 & $\begin{array}{l}\text { I feel that Dubai Expo } 2020 \text { will bring more positive impacts to society and culture } \\
\text { than negative impacts. }\end{array}$ & 3.39 & 0.93 & 11 & $51 \%$ \\
\hline \multicolumn{6}{|c|}{ Involvement and participation } \\
\hline 24 & I know details about Dubai world Expo 2020 & 2.85 & 0.86 & NA & $25 \%$ \\
\hline 25 & $\begin{array}{l}\text { I feel involved in organizing the event (I received news/updates through } \\
\text { SMSs/emails) }\end{array}$ & 3.41 & 1.01 & NA & $47 \%$ \\
\hline 26 & I feel like promoting this event & 3.53 & 0.96 & NA & $53 \%$ \\
\hline 27 & I want to participate in the event through volunteer activities & 3.77 & 0.98 & NA & $64 \%$ \\
\hline
\end{tabular}

Exploratory factor analysis was carried out to check the factor loadings (Table 4), followed by confirmatory factor analysis.

Table 4. Factor Loadings from the Exploratory Factor Analysis.

\begin{tabular}{|c|c|c|c|c|c|c|c|}
\hline & 1 & 2 & 3 & 4 & 5 & 6 & 7 \\
\hline Employment Generation & 0.673 & & & & & & \\
\hline Economic Investment & 0.711 & & & & & & \\
\hline Living Standards & 0.779 & & & & & & \\
\hline Infrastructure & 0.668 & & & & & & \\
\hline Tourism & 0.598 & & & & & & \\
\hline More +ve economic impacts & 0.651 & & & & & & \\
\hline More +ve environment impacts & & & & & & 0.651 & \\
\hline Preservation of environment & & & & & & 0.509 & \\
\hline Feeling proud & & 0.797 & & & & & \\
\hline Dubai as a destination brand & & 0.810 & & & & & \\
\hline Recreation facilities & & 0.790 & & & & & \\
\hline More +ve social impacts & & 0.679 & & & & & \\
\hline Knowledge of event details & & & & 0.601 & & & \\
\hline Feeling involved & & & & 0.811 & & & \\
\hline Feeling to promote & & & & 0.756 & & & \\
\hline Willingness to participate & & & & 0.636 & & & \\
\hline Price increase & & & & & -0.714 & & \\
\hline Real estate price increase & & & & & -0.612 & & \\
\hline Fear to lose employment & & & & & -0.504 & & \\
\hline Pollution increase & & & -0.637 & & & & \\
\hline Population increase & & & -0.617 & & & & \\
\hline Traffic increase & & & -0.629 & & & & \\
\hline Destroy of nature & & & -0.461 & & & & \\
\hline Danger to local culture & & & & & & & -0.596 \\
\hline Anti- social elements & & & & & & & -0.683 \\
\hline Low living quality & & & & & & & -0.591 \\
\hline Inconvenience & & & & & & & -0.749 \\
\hline
\end{tabular}


In order to assess the relationship between perceived impacts and the level of involvement, a measurement model based on confirmatory factor analysis was utilized. The results indicated that the model fitted the empirical data as the model parameters, such as GFI $=0.976$, RMR $=108$, and RMSEA = 0.120, Chi-Square-1401.962, Df-303.000, CMIN/df = 4.62, AGFI-0.962, TLI-0.973, NFI-0.970, CFI-0.976, PGFI-0.658 all have acceptable values. The average variance extracted for the latent variables is above 0.5 (Table 5). Table 6shows the standardized effects of the measurement model which are found to be statistically significant $(p<0.001)$.

Table 5. Average variance extracted.

\begin{tabular}{cc}
\hline Latent Variables & Average Variance Extracted (AVE) \\
\hline Positive Economic & 0.6800988 \\
\hline Positive environment & 0.5075643 \\
\hline Positive social & 0.7718921 \\
\hline Involvement & 0.7474438 \\
\hline Negative Economic & 0.5685829 \\
\hline Negative Environment & 0.5783991 \\
\hline Negative Social & 0.7348599 \\
\hline
\end{tabular}

Table 6. Standardized effects of the measurement model.

\begin{tabular}{|c|c|c|c|c|c|}
\hline Variable & Predictor & Estimate & Standard Error & Z Value & $\operatorname{Pr}>|Z|$ \\
\hline ECONINVST & Positive Economic & 1.439 & 0.116 & 12.397 & $<0.0001$ \\
\hline LIVSTND & Positive Economic & 1.059 & 0.038 & 27.589 & $<0.0001$ \\
\hline EMPLOY & Positive Economic & 1.020 & 0.043 & 23.883 & $<0.0001$ \\
\hline INFRAST & Positive Economic & 0.992 & 0.049 & 20.072 & $<0.0001$ \\
\hline TOURISM & Positive Economic & 0.843 & 0.053 & 15.893 & 0.0028 \\
\hline MOREPOSITIVE & Positive Economic & 0.824 & 0.047 & 17.358 & $<0.0001$ \\
\hline PRESENVIRON & Positive environment & 1.756 & 0.114 & 15.387 & $<0.0001$ \\
\hline MOREPOSIENV & Positive environment & 1.428 & 0.115 & 12.422 & $<0.0001$ \\
\hline PROUD & Positive social & 1.288 & 0.091 & 14.128 & $<0.0001$ \\
\hline BRAND & Positive social & 1.051 & 0.037 & 28.458 & $<0.0001$ \\
\hline RECREATIO & Positive social & 1.022 & 0.043 & 23.573 & $<0.0001$ \\
\hline MOREPOSTSOCIETY & Positive social & 0.820 & 0.061 & 13.453 & $<0.0001$ \\
\hline KNOWDETAILS & Involvement & 1.595 & 0.148 & 10.809 & $<0.0001$ \\
\hline FEELINVOLV & Involvement & 1.386 & 0.048 & 28.925 & $<0.0001$ \\
\hline PROMOTING & Involvement & 1.310 & 0.038 & 34.446 & $<0.0001$ \\
\hline PARTICIPATING & Involvement & 1.079 & 0.040 & 26.860 & $<0.0001$ \\
\hline PRICEINC & Negative Economic & 2.149 & 0.097 & 22.180 & $<0.0001$ \\
\hline REALESTATE & Negative Economic & 1.534 & 0.464 & 3.309 & $<0.0001$ \\
\hline LOOSEJOB & Negative Economic & -0.953 & 1.016 & -0.938 & 0.348 \\
\hline POLLUTION & Negative Environment & 1.528 & 0.093 & 16.494 & $<0.0001$ \\
\hline POPULATION & Negative Environment & 1.529 & 0.117 & 13.093 & $<0.0001$ \\
\hline TRAFFIC & Negative Environment & 1.083 & 0.116 & 9.370 & $<0.0001$ \\
\hline DESTROYNATURE & Negative Environment & -0.028 & 0.186 & -0.149 & 0.881 \\
\hline DANGERCULTURE & Negative Social & 1.093 & 0.046 & 21.515 & $<0.0001$ \\
\hline ANTISOCIAL & Negative Social & 1.002 & 0.150 & 6.674 & $<0.0001$ \\
\hline LOWQUALITY & Negative Social & 1.110 & 0.052 & 21.515 & $<0.0001$ \\
\hline INCONVENIENCE & Negative Social & 0.729 & 0.061 & 12.020 & $<0.0001$ \\
\hline
\end{tabular}

Full structural model is used to identify hypothesis and test the relationship between the latent constructs through six assumptions which were pertaining to the correlations among the perceived economic, sociocultural, environmental impacts and the level of involvement in the event. The results are shown in Table 7. 
Table 7. Analysis of Parameter significance.

\begin{tabular}{lllccccc}
\hline & Path & & Parameter & Estimate & Standard Error & Z Value & Pr $>|\mathrm{Z}|$ \\
\hline v1poseco & $===>$ & v7involve & _Parm1 & 0.608 & 0.040 & 3.680 & 0.000 \\
v3posenv & $===>$ & v7involve & _Parm2 & 0.473 & 0.035 & 6.485 & 0.000 \\
v5possoc & $===>$ & v7involve & _Parm3 & 0.681 & 0.043 & 7.211 & 0.000 \\
v2negeco & $===>$ & v7involve & Parm4 & 0.178 & 0.025 & 9.515 & 0.000 \\
v4negenv & $===>$ & v7involve & _Parm5 & 0.006 & 0.051 & 3.424 & 0.000 \\
v6negsoc & $===>$ & v7involve & _Parm6 & -0.332 & 0.044 & 2.870 & 0.000 \\
\hline
\end{tabular}

Figure 2 shows the coefficients of the path model reflecting the association among the perceived impacts and residents' level of involvement in organizing Expo 2020. Out of the six-path hypothesis, four are statistically supported whereas two path hypothesis, namely H1b: "Negative Economic Perception of Expo 2020 negatively impacts involvement of residents towards Expo 2020" and H3b: “Negative Environmental Perception of Expo 2020 negatively impacts involvement of residents towards Expo 2020" were rejected.

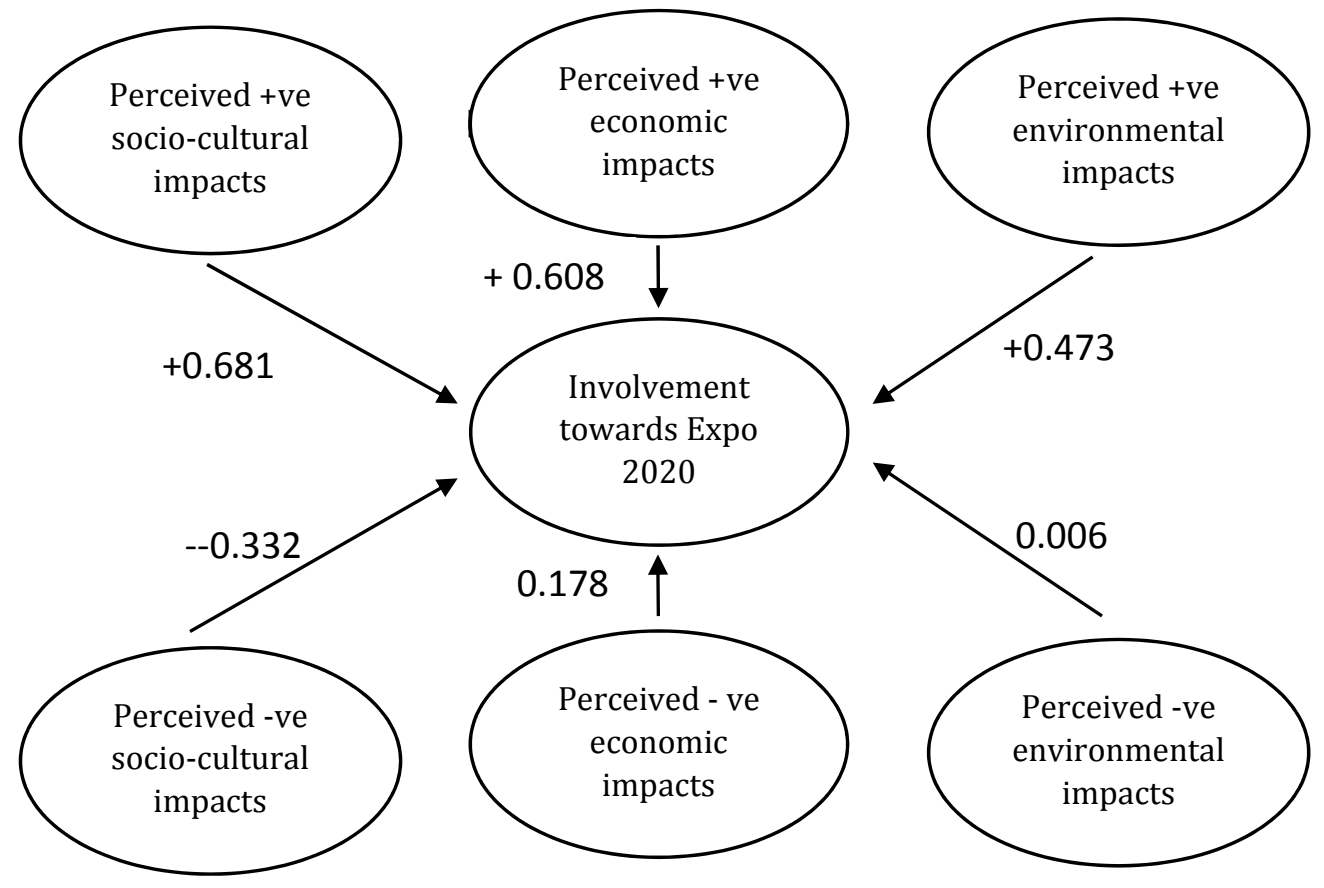

Figure 2. Results of standardized estimated hypothetical model.

The results show that the residents' perceptions of their involvement tend to an increase with perceived socio-cultural impacts $(+0.681)$ followed by perceived positive economic impacts $(+0.608)$ and lastly perceived environmental impacts $(+0.473)$. Overall the respondents seem to be quite concerned about the potential socio-cultural and economic impacts, rather than its environmental impacts. Although more than 60 percent and 70 percent of the respondents expect the event to spur economic investments and tourism, respectively; 84 percent and 83 percent foresee an increase in real estate prices and general inflation, respectively, due to the event (Table 3). The results might be influenced by a significant increase in residential rental activity with average rents increasing by over 25 percent in 2013, which followed a 16 percent increase over 2012. The announcement of Dubai winning the Expo 2020 bid resulted in Dubai's consumer inflation rising by 3.0 percent in March 2013 contrasted with the same month in 2012, this being the most astounding increment since August 2009. Lodging and utility costs, which account for almost 44 per cent of consumer expenses, climbed 4.8 percent year-on-year and food and beverage prices, which account for 11 percent of the basket, likewise climbed 4.8 percent from a year sooner and increased 1.2 percent from a month sooner. It also 
appears that less than half of the respondents (48 percent) agreed on Expo 2020's positive economic impacts reaching them via generation of employment and improvements in their living standards. Subsequently, a sizeable proportion of the respondents are not able to connect themselves with the likely positive economic impacts. The results indicate that the residents although have reasonable confidence in Dubai to organize the event successfully and possess positive perceptions towards the event's impact on the economy yet strong concerns about the increased property prices and inflation in general, due to the event announcement.

Although the positive environmental perception of Expo 2020 positively impacts involvement of residents $(+0.473)$ the association was absent $(0.006)$ between perceived negative environmental impacts and residents' involvement which means that respondents who even perceive negative environmental impacts were not discouraged to participate and get involved in the event! Therefore, though path hypothesis H3a: "Positive Environmental Perception of Expo 2020 positively impacts involvement of residents towards Expo 2020" was accepted yet path hypothesis H3b: "Negative Environmental Perception of Expo 2020 negatively impacts involvement of residents towards Expo $2020^{\prime \prime}$ was rejected. It is to be noted that the country has been in limelight due to the increased carbon foot prints and energy consumption. The environmentalists blame large scale developments, such as manmade islands, skyscrapers, shopping malls, artificial ski resorts and others as the cause behind such high carbon emissions. The country has been focused on reducing the carbon emissions resulting in an increased environment awareness which might have gained residents' confidence reflecting in these results. Table 3 shows that 47 percent of the respondents expressed their apprehension for a possible increase in traffic congestion due to the event, followed by 45 percent voicing against pollution that might happen due to the event (Table 3). More than a quarter of the respondents (29 percent) believed in the fact that the revenues gained from the event would be utilized for preserving and conserving the environment. Although only 8 percent said that the construction of infrastructure and other facilities for the event would lead to damaging the natural environment, 53 percent of respondents believed in positive impacts outweighing the negative environmental impacts.

Path hypothesis H2a: "Positive Social Perception of Expo 2020 positively impacts involvement of residents towards Expo 2020" was supported $(+0.681)$, though mixed results were received when the questions related to socio-cultural issues were asked to the respondents. Nearly 52 percent of the respondents agreed to the fact that the event would strengthen the destination image, followed by 50 percent who believed in the development of recreational facilities which could be used by them once the event concludes (Table 3). Almost one third of the respondents were concerned about the inconvenience to the general public caused due to the event. Less than one fourth of the respondents showed their concern about an increase in anti-social elements due to the event, which demonstrates their confidence in law and order maintained in the country for a long time. Only 8 percent of the respondents said that the event would negatively affect their traditions and culture, which might be a reflection of a huge multi-national community living in the country. Although only 9 percent of the respondents believed in the fact that the event will lead to a preference given to the visitors over residents, half of the respondents agreed on event bringing positive socio-cultural impacts on the community. Interestingly, 48 percent of the respondents possessed a feeling of pride for being part of the country organizing the mega event. The organizers have been quite strong in media and publicity and have been continuously sending text messages (Figure 3) to the residents, however there remains scope for further improvement in their level of involvement. For instance, residents could be invited to volunteer in the event as has been the practice for the previous world expos. Nearly one fourth of the respondents knew details about the event and 47 percent said that they received news/updates about the event, through text messages/emails. While 53 percent of the respondents said they would like to promote the event, a sizable number of respondents (64 percent) showed their inclination towards participating in the event through volunteer activities.

Ironically, despite having few concerns about the negative impacts of the mega event, overall the respondents were quite positive to participate and get involved in organizing it. Only two elements; 
one in the negative economic impacts "loosing employment" and second in the negative environmental impacts (destroy of nature) were supported in terms of adversely affecting the involvement. One reason behind the positive inclination might be the nation-wide campaigns initiated by different ministries and the organizers.

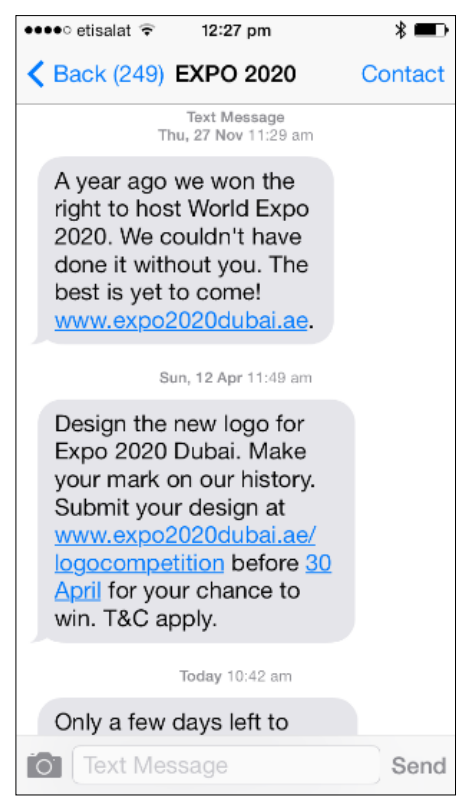

Figure 3. Text message sent from the Expo organizers to the residents' mobile phones.

\section{Conclusions and Managerial Implications}

The study has attempted to examine the perceptions of residents towards a mega event which in this case is the World Expo to be held in Dubai in the year 2020. The results of the study indicate that in general, the residents of Dubai carry positive perceptions towards the possible impacts of the event on their lives. However, there were a few gaps identified by the study. Firstly, it is found that there is a possibility of a trade-off between the economic benefits generated by the World Expo and the inconvenience that the event may cause to the residents. For instance, while acknowledging the economic advantages in terms of investments that the World Expo would bring, the residents are concerned about traffic and congestion issues that the event might cause. Another notable finding is about the residents being worried about an increase in property prices/rents and inflation in general, and believe Expo 2020 to be the major reason behind it. Nevertheless, responses significantly indicate residents' perceptions about the positive economic impacts outweighing the negative economic impacts that may be caused due to Expo 2020. In contrast, the respondents expressed their concerns about an increase in population, pollution and congestion which could adversely affect the environment. Though the organizers have planned a variety of activities showcasing usage of renewable energy sources, yet the relevance and impact towards conserving nature and environment are yet to be acknowledged by the residents. The results of the study also reveal that the residents carry strong positive perceptions about the socio-cultural impacts of the event. One reason behind this finding could be the distinctive demographic characteristic of the emirate where the expatriates contribute a significant 91.7 percent to the total population [67].Hailing from more than 200 countries, these expatriates have been working and dealing with one another and have developed multicultural bonding. The residents also declined to expect major harm by anti-social elements, such as drugs or prostitution due to the event, which is a good sign and reflects the presence of law and order enforcement in the country. However, the respondents who perceived negative socio-cultural impacts of the event also showed discouragement towards participating in the event. A significant portion of the respondents believed in the event bringing more positive socio-cultural impacts than negative ones, 
via new recreation facilities and infrastructural developments which could be utilized by both the visitors and the residents. Although the event has been perceived as a matter of pride for a significant portion of the population and they seemed to be excited in terms of participation and promotion of the event, only a quarter of respondents agreed on knowing details about the event. One reason for this could be limited awareness of event related campaigns; however, the effectiveness of these may improve closer to the date of the event. It is also noted during the data collection that while "sustainability" remains one of the three major themes of the event and the organizers believe the event to be "a landmark in sustainable development", the residents are yet to have an understanding about the same.

Based on the stakeholder theory, the results of the study focused on the importance of taking local residents in confidence for organizing any successful event. It is imperative for the organizers to analyze residents' interests while organizing a mega event, such as Expo 2020, and ascertain that the residents are well compensated in terms of social, economic and environmental benefits. Although these mega events come up with huge employment opportunities, keeping them sustainable, remains a challenge. The organizers for Dubai Expo 2020 have so far done an excellent job for winning the bid and laying out an appealing and much desired theme for the event. However, the organizers have yet to communicate the way in which the incremental benefits of the event would contribute to residents' lives. It seems that the residents are aware of the larger picture but not their respective roles and prospective personal gains out of the event. The organizers are suggested to equally focus on developing a road map for creating opportunities for residents and how to involve them in organizing the event. It is understandable that not everyone could be directly involved, yet all of them should be at least aware of the indirect and induced benefits through the event. The organizers in addition to disseminating event details through text messages, may also create a team of volunteers for conducting awareness interactive sessions in schools, universities, public and private organizations to establish palpable connect and relationships. Encouraging educational institutes on organizing sub events on the Expo 2020 theme, such as debate competitions, poster making and so on could easily gain attention from the youth, who would play a major role in volunteering for activities during the event in 2020. Lastly, the organizers may as well demonstrate how the event will contribute to impact the environment positively enhancing residents' understanding of the theme and positive implications on their lives.

\section{Limitations and Future Research}

A unique feature of this study is the a-priori deduction of results, having been conducted before the event is staged; the perceived impacts can later be compared with actual impacts with another possible study conducted after the event is over. This, however remains to be a first step in understanding residents' perceptions about the way in which Expo 2020 might impact them. Further limitations must be acknowledged whereby an attempt was made to include respondents from various demographic groups, the sample was of limited size and skewed in terms of aspects, such as gender. There is still a time span of one and half year which can be utilized for conducting similar kind of research on a larger and more representative sample of respondents, generating more reliable results. Further research can be conducted on exploring the possible association between the demographic characteristics of the residents' and their perceptions about the event. This would enable the organizers to identify the gaps in detail, and target their activities towards identified profiles of the respondents. Future research could also take a longitudinal approach, comparing perceptions prior to, during and after the conclusion of the event when its impacts are fresh in the minds of respondents.

Author Contributions: Conceptualization, M.V., A.U., A.V. and M.K.; Methodology, M.V., A.U.; Software, M.V., A.U., A.V.; Validation, A.U. and A.V.; Formal Analysis, M.V., A.U., A.V. and M.D, Data Curation, M.V. and A.U.; Writing-Original Draft Preparation, M.V., A.U. and A.V.; Writing-Review and Editing, A.V. and M.K.

Funding: This research received no external funding. 
Acknowledgments: The authors are thankful to Mr Vinaitheerthan, Head, IR Office, Skyline University College for technical support and the students' team for data collection.

Conflicts of Interest: The authors declare no conflict of interest.

\section{References}

1. Bowdin, G.; McPherson, G.; Flinn, J. Identifying and Analyzing Existing Research Undertaken in the Events Industry: A literature Review for People; Association for Events Management Education: Leeds, UK, 2006.

2. Müller, M. What makes an event a mega-event? Definitions and sizes. Leis. Stud. 2015, 34, 627-642. [CrossRef]

3. Chen, Y.; Qu, L.; Spaans, M. Framing the Long-Term Impact of Mega-Event Strategies on the Development of Olympic Host Cities. Plan. Pract. Res. 2013, 28, 340-359. [CrossRef]

4. Tsaur, S.-H.; Yen, C.-H.; Tu, J.-H.; Wang, C.-H.; Liang, Y.-W. Evaluation of the 2010 Taipei International Flora Exposition from the perceptions of host-city residents: A new framework for mega-event legacies measurement. Leis. Stud. 2017, 36, 65-88. [CrossRef]

5. Lee, J.; Kyle, G.; Scott, D. The Mediating Effect of Place Attachment on the Relationship between Festival Satisfaction and Loyalty to the Festival Hosting Destination. J. Travel Res. 2012, 51, 754-767. [CrossRef]

6. Bull, C.; Lovell, J. The Impact of Hosting Major Sporting Events on Local Residents: An Analysis of the Views and Perceptions of Canterbury Residents in Relation to the Tour de France 2007. J. Sport Tour. 2007, 12, 229-248. [CrossRef]

7. Lamberti, L.; Noci, G.; Guo, J.; Zhu, S. Mega-events as drivers of community participation in developing countries: The case of Shanghai World Expo. Tour. Manag. 2011, 32, 1474-1483. [CrossRef]

8. Choi, H.C.; Sirakaya, E. Sustainability indicators for managing community tourism. Tour. Manag. 2006, 27, 1274-1289. [CrossRef]

9. Ye, X.; Scott, N.; Ding, P.; Huang, Y. Residents' attitudes toward the 2010 World Expo in Shanghai prior to and during the event. J. Sustain. Tour. 2012, 20, 1087-1105. [CrossRef]

10. De Groote, P. A multidisciplinary analysis of world fairs (=expos) and their effects. Tour. Rev. 2005, 60, 12-19. [CrossRef]

11. Walvis, T. Three Eras of World Expositions: 1851-Present. Cosmopolite: Stardust World Expo \& National Branding Newsletter: Amsterdam, The Netherlands, 2004.

12. Vij, M.; Vij, A. Tourism and Carbon Foot Prints in United Arab Emirates-Challenges and Solutions. J. Environ. Manag. Tour. 2012, 3, 41-54. [CrossRef]

13. Gulf News. 15.8 Million People Visited Dubai in 2017. Gulf News 2018. Available online: https:/ /gulfnews. com/business/tourism/158-million-people-visited-dubai-in-2017-1.2169807 (accessed on 18 June 2018).

14. Gulf News. Dubai Moves One Step Closer to World Expo 2020. Gulf New 2013. Available online: http:/ / gulfnews. $\mathrm{com} /$ business/sectors/general/dubai-moves-one-step-closer-to-world-expo-2020-1.1195922 (accessed on 18 June 2018).

15. Freeman, R.E. Strategic Management: A Stakeholder Approach, 1st ed.; Harpercollins College Div: Boston, MA, USA, 1984.

16. Donaldson, T.; Preston, L.E. The Stakeholder Theory of the Corporation: Concepts, Evidence, and Implications. Acad. Manag. Rev. 1995, 20, 65-91. [CrossRef]

17. Clarkson, M.B.E. A Stakeholder Framework for Analyzing and Evaluating Corporate Social Performance. Acad. Manag. Rev. 1995, 20, 92-117. [CrossRef]

18. Byrd, E.T.; Cárdenas, D.A.; Greenwood, J.B. Factors of stakeholder understanding of tourism: The case of Eastern North Carolina. Tour. Hosp. Res. 2008, 8, 192-204. [CrossRef]

19. Nanz, P.; Steffek, J. Global Governance, Participation and the Public Sphere. Gov. Oppos. 2004, 39, $314-335$. [CrossRef]

20. Cerutti, S. Religious Tourism and Event Management: An Opportunity for Local Tourism Development. Dublin Inst. Technol. 2015. [CrossRef]

21. Raj, R.; Walters, P.; Rashid, T. Events Management: Principles and Practice, 2nd ed.; SAGE Publications Ltd.: London, UK, 2013.

22. Arcodia, C.; Barker, T. The Employability Prospects of Graduates in Event Management: Using Data from Job Advertisements. In Proceedings of the Riding the Wave of Tourism and Hospitality Research, CAUTHE, Coffs Harbour, Australia, 5-8 February 2003. 
23. Deery, M.; Jago, L. Social impacts of events and the role of anti-social behaviour. Int. J. Event Festiv. Manag. 2010, 1, 8-28. [CrossRef]

24. Jago, L.; Dwyer, L.; Lipman, G.; van Lill, D.; Vorster, S. Optimising the potential of mega-events: An overview. Int. J. Event Festiv. Manag. 2010, 1, 220-237. [CrossRef]

25. Ferrari, S.; Guala, C. Mega-events and their legacy: Image and tourism in Genoa, Turin and Milan. Leis. Stud. 2014, 36, 119-137. [CrossRef]

26. Parent, M.M.; Rouillard, C.; Naraine, M.L. Network governance of a multi-level, multi-sectoral sport event: Differences in coordinating ties and actors. Sport Manag. Rev. 2017, 20, 497-509. [CrossRef]

27. Augustyn, M.M.; Knowles, T. Performance of tourism partnerships: A focus on York. Tour. Manag. 2000, 21, 341-351. [CrossRef]

28. de Araujo, L.M.; Bramwell, B. Partnership and regional tourism in Brazil. Ann. Tour. Res. 2002, 29, 1138-1164. [CrossRef]

29. Fyall, A.; Callod, C.; Edwards, B. Relationship Marketing: The Challenge for Destinations. Ann. Tour. Res. 2003, 30, 644-659. [CrossRef]

30. Lankford, S.V.; Howard, D.R. Developing a tourism impact attitude scale. Ann. Tour. Res. 1994, 21, 121-139. [CrossRef]

31. Tosun, C. Expected nature of community participation in tourism development. Tour. Manag. 2006, 27, 493-504. [CrossRef]

32. Vij, A. Dubai EXPO 2020-Exploring the drivers impacting sustained changes in UAE Economy. Res. J. Econ. Bus. Stud. 2016, 5, 9.

33. Simão, J.; Môsso, A. Residents' perceptions towards tourism development: The case of Sal Island. Int. J. Dev. Issues 2013, 12, 140-157. [CrossRef]

34. Yang, J.; Zeng, X.; Gu, Y. Local Residents' Perceptions of the Impact of 2010 EXPO. J. Conv. Event Tour. 2010, 11, 161-175. [CrossRef]

35. Li, X.; Hsu, C.H.C.; Lawton, L.J. Understanding residents' perception changes toward a mega-event through a dual-theory lens. J. Travel Res. 2015, 54, 396. [CrossRef]

36. Li, H.; Schein, D.; Ravi, S.; Song, W.; Gu, Y. Factors influencing residents' perceptions, attitudes and behavioral intention toward festivals and special events: A pre-event perspective. J. Bus. Econ. Manag. 2018, 19, 288-306. [CrossRef]

37. Balduck, A.; Maes, M.; Buelens, M. The social impact of the Tour de France: Comparisons of residents' preand post-event perceptions. Eur. Sport Manag. Q. 2011, 11, 91-113. [CrossRef]

38. Sherwood, P. A Triple Bottom Line Evaluation of the Impact of Special Events: The Development of Indicators. Ph.D. Thesis, Victoria University, Melbourne, Victoria, Australia, 2007.

39. Dwyer, L.; Jago, L.; Forsyth, P. Economic evaluation of special events: Reconciling economic impact and cost-benefit analysis. Scand. J. Hosp. Tour. 2016, 16, 115-129. [CrossRef]

40. Wise, N. Outlining triple bottom line contexts in urban tourism regeneration. Cities 2016, 53, 30-34. [CrossRef]

41. Stoddard, J.E.; Pollard, C.E.; Evans, M.R. The triple bottom line: A framework for sustainable tourism development. Int. J. Hosp. Tour. Adm. 2012, 13, 233-258. [CrossRef]

42. Byrd, E.T.; Gustke, L.D. Identifying tourism stakeholder groups based on support for sustainable tourism development and participation in tourism activities. Sustain. Tour. 2004, 76. [CrossRef]

43. Fleischer, A.; Felsenstein, D. Support for rural tourism: Does it make a difference? Ann. Tour. Res. 2000, 27, 1007-1024. [CrossRef]

44. Sirakaya, E.; Teye, V.; Sönmez, S. Understanding Residents' Support for Tourism Development in the Central Region of Ghana. J. Travel Res. 2002, 41, 57-67. [CrossRef]

45. Perdue, R.R.; Long, P.T.; Allen, L. Resident support for tourism development. Ann. Tour. Res. 1990, 17, 586-599. [CrossRef]

46. Andereck, K.L.; Valentine, K.M.; Knopf, R.C.; Vogt, C.A. Residents' perceptions of community tourism impacts. Ann. Tour. Res. 2005, 32, 1056-1076. [CrossRef]

47. Ghaderi, Z.; Henderson, J.C. Sustainable rural tourism in Iran: A perspective from Hawraman Village. Tour. Manag. Perspect. 2012, 2-3, 47-54. [CrossRef]

48. Jimura, T. The impact of world heritage site designation on local communities-A case study of Ogimachi, Shirakawa-mura, Japan. Tour. Manag. 2011, 32, 288-296. [CrossRef] 
49. Mason, P.; Cheyne, J. Residents' attitudes to proposed tourism development. Ann. Tour. Res. 2000, 27, 391-411. [CrossRef]

50. Nicholas, L.N.; Thapa, B.; Ko, Y.J. Residents' perspectives of a world heritage site: The Pitons Management Area, St. Lucia. Ann. Tour. Res. 2009, 36, 390-412. [CrossRef]

51. Pranić, L.; Cetinić, L.; Petrić, L. Host population perceptions of the social impacts of sport tourism events in transition countries: Evidence from Croatia. Int. J. Event Festiv. Manag. 2012, 3, 236-256. [CrossRef]

52. Kim, H.J.; Gursoy, D.; Lee, S.-B. The impact of the 2002 World Cup on South Korea: Comparisons of pre- and post-games. Tour. Manag. 2006, 27, 86-96. [CrossRef]

53. Dwyer, L.; Mellor, R.; Mistilis, N.; Mules, T. A framework for assessing 'tangible' and 'intangible' impacts of events and conventions. Event Manag. 2000, 6, 175-189.

54. Gursoy, D.; Kendall, K.W. Hosting mega events: Modeling locals' support. Ann. Tour. Res. 2006, 33, 603-623. [CrossRef]

55. Kim, S.S.; Petrick, J.F. Residents' perceptions on the impacts of the FIFA 2002 World Cup: The case of Seoul as a host city. Tour. Manag. 2005, 26, 25-38. [CrossRef]

56. Wood, E. Measuring the economic and social impacts of local authority events. Int. J. Public Sect. Manag. 2005, 18, 37-53. [CrossRef]

57. Ma, S.-C.; Egan, D.; Rotherham, I.; Ma, S.-M. A framework for monitoring during the planning stage for a sports mega-event. J. Sustain. Tour. 2011, 19, 79-96. [CrossRef]

58. Ritchie, B.W.; Shipway, R.; Cleeve, B. Resident perceptions of mega-sporting events: A non-host city perspective of the 2012 London Olympic Games. J. Sport Tour. 2009, 14, 143-167. [CrossRef]

59. Zhou, Y.; Ap, J. Residents' perceptions towards the impacts of the Beijing 2008 Olympic Games. J. Travel Res. 2009, 48, 78-91. [CrossRef]

60. Lorde, T.; Greenidge, D.; Devonish, D. Local residents' perceptions of the impacts of the ICC Cricket World Cup 2007 on Barbados: Comparisons of pre- and post-games. Tour. Manag. 2011, 32, 349-356. [CrossRef]

61. Henderson, J.C.; Foo, K.; Lim, H.; Yip, S. Sports events and tourism: The Singapore Formula One Grand Prix. Int. J. Event Festiv. Manag. 2010, 1, 60-73. [CrossRef]

62. Molloy, J. Regional festivals: A look at community support, the isolation factor and funding sources. J. Tour. Stud. 2002, 13, 2-16.

63. Sharma, B.; Dyer, P. Residents' involvement in tourism and their perceptions of tourism impacts. Benchmarking 2009, 16, 351-371. [CrossRef]

64. Arthur, D.; Andrew, J. Incorporating community involvement in the management of sporting mega-events: An Australian Case study. Festiv. Manag. Event Tour. 1996, 4, 21-28. [CrossRef]

65. Nunkoo, R.; Gursoy, D. Residents' support for tourism an identity perspective. Ann. Tour. Res. 2012, 39, 243-268. [CrossRef]

66. Booth, K.L. Recreation and Tourism Research for Conservation. 1988. Available online: https://www.doc. govt.nz/globalassets / documents / science-and-technical/srir10.pdf (accessed on 5 June 2018).

67. Dubai Statistics Center Number of Population Estimated by Nationality_Emirate of Dubai (2017-2015). Available online: https://www.dsc.gov.ae/Report/DSC_SYB_2017_01\%20_\%2003.pdf (accessed on 2 June 2018).

(C) 2019 by the authors. Licensee MDPI, Basel, Switzerland. This article is an open access article distributed under the terms and conditions of the Creative Commons Attribution (CC BY) license (http:// creativecommons.org/licenses/by/4.0/). 